\title{
The Effectiveness Of The Hope Family Program From Education, Health, Welfare, And Psychological Aspects In Buleleng District
}

\author{
Dewa Bagus Sanjaya $^{1}$, Dewa Ayu Puteri Handayani ${ }^{1}$, Dewa Gede Firstia Wirabrata ${ }^{1}$, I Made \\ Riyan Cahyadi ${ }^{1}$, Ni Made Widya Sari ${ }^{1}$
}

\{bagus.sanjaya@undiksha.ac.id, ayu.puteri@undiksha.ac.id, firstia.wirabrata@undiksha.ac.id\}

${ }^{1}$ Universitas Pendidikan Ganesha, Indonesia

\begin{abstract}
This study aims to analyze: (1) the effectiveness of the implementation of the Beneficiary Families of the Family Hope Program (PKH) in Buleleng District, (2) Analyzing the psychological picture of the PKH beneficiary families in Buleleng District. This study uses a research design evaluation using descriptive analysis percentage. The location of this research is in Buleleng District, with a total ppopulation of 2117 people. While the research sample was determined by purposive sampling with a total of 200 people. This research data collected using the $\mathrm{k}$ methodquestionnaire, interviews, documentation, and observations. The results showed that at In terms of input, there are still 33.68 PKH recipients who do not meet the requirements to become PKH recipients. Aspects of the process, the implementation of PKH is considered to have been running effectively. As for the output aspect, the majority of respondents $(63.3 \%)$ have carried out their obligations as PKH recipients well, while $33.7 \%$ still have not shown satisfactory results. Psychological aspect, this PKH program turned out to have quite a positive psychological impact.
\end{abstract}

Keywords: The Effectiveness of the Family Hope Program, in Buleleng District

\section{Introduction}

The problem of poverty is a very complex problem, so it requires special attention. One of the social problems as a result of poverty is the low level of education. Poverty can cause an increase in the number of children who drop out of school who come from poor families (KM) and can affect public health conditions, namely their vulnerability to disease and the risk of malnutrition. DLooking at the numbers, according to Suardika [1] the number of poor people in Buleleng Regency in 2019 was 34,260 people. Meanwhile, in 2020, the number of poor people will increase to 35,250 people.

As an effort to accelerate poverty reduction, since 2007 the Government of Indonesia has implemented the Family Welfare Program (PKH). The Social Protection Program is also known internationally as Conditional Cash Transfers (CCT). This program is quite successful in tackling poverty in countries that receive this program, especially the problem of chronic poverty. As a conditional social assistance program, PKH opens access for poor families, especially pregnant women and children, to take advantage of the various available health service facilities (faskes) and educational service facilities (fasdik). 
Through PKH, poor families are encouraged to have access to and utilize basic social services of health, education, food, nutrition, care, and assistance, including access to various other social protection programs which are complementary programs on an ongoing basis. $\mathrm{PKH}$ is directed to be the epicenter and center of excellence for poverty reduction that synergizes various national social protection and empowerment programs.

PKH's mission to reduce poverty is becoming increasingly prominent considering that the number of poor people in Indonesia until March 2016 was still $10.86 \%$ of the total population or 28.01 million people [2]. The government has set a poverty reduction target of 7-8\% in 2019, as stated in the 2015-2019 RPJMN. In March 2020, the number of poor people reached 26.42 million people. This amount is equivalent to $9.78 \%$ of the population. $\mathrm{PKH}$ and other poverty reduction programs are expected to contribute significantly and synergistically in reducing the number of poor people, improving the quality of human resources (HR) who are still less skilled in Buleleng district.

Effectivef is the ability to do something right. Effectiveness has a lot to do with goals because the closer an organization is to its goals, the more effective it is. There are several opinions in translating the notion of effectiveness, where this difference of opinion is due to differences in the framework used. According to Richard M. Steers who argues that effectiveness can be assessed according to the size of how far an organization has succeeded in achieving organizational goals that are worth achieving. To find out the effectiveness of an activity, we can use the five correct theories proposed by Matland in his book Nugroho, namely the right policy, the right implementation, the right target, the right environment and the right process. According to Subagyo in the journal of economics and social, effectiveness is the match between the output and the goals set. Effectiveness is a condition that occurs because it is desired. If a person performs an act with a specific purpose and it is desired, then that person's work is said to be effective if it causes consequences or has the intended purpose.

Effectiveness is also the achievement of organizational goals through the efficient use of available resources, in terms of inputs, processes, and outputs. In this case, what is meant by resources includes the availability of personnel, facilities and infrastructure as well as the methods and models used. An activity is said to be efficient if it is carried out correctly and in accordance with procedures, while it is effective if the activity is carried out correctly and with useful results. So that program effectiveness can be formulated as the level of realization of targets that indicate the extent to which the program targets have been set, whether they provide results in accordance with the program objectives or not.

The Family Hope Program (PKH) is a program policy formulated by the Government to address the problem of population poverty in Indonesia. In general, the concept of policy is almost always associated with permanent decisions that are consistent in nature and are a repetition of the behavior of those who make and those who comply with these decisions (Sarman, 2000). Policy is an action that leads to the goals proposed by a person, group or government in a certain environment in connection with certain obstacles while looking for opportunities to achieve the desired goals, in relation to the functional role of the Government in the public sphere as a public servant.

Referring to Nugroho [3], to solve problems that develop in society, policies are needed as a realization of the functions and tasks of the state and in order to achieve development goals. In other words, policies (in the context of the Government's role as a public authority) are needed to solve problems that exist in the public sphere. And for that we need not only the formulation (plan) of the program, but also the implementation of the program in order to achieve the 
planned goals. Therefore, a policy must be implemented in order to have an impact on the desired goals [4].

Policy implementation is an effort to achieve goals by means and in a certain time sequence. The implementation of the program policy can only begin if the policy objectives have been set, action programs have been created, and funds to support the implementation of the action program have been allocated for the achievement of the policy objectives (Wibawa, 2004). In the context of the PKH model, the basic strategy is how to provide social protection for RTSM. Referring to ADB [5] the concept of social protection is intended as a set of social welfare policies designed to reduce poverty and vulnerability through the expansion of an efficient labor market, reducing the risks to life that constantly threaten human beings,

However, according to Norton [6] social protection is a policy aimed at groups of people who experience conditions that are vulnerable either in absolute terms or the vulnerability of the poorest. In addition, it can be addressed to non-poor community groups for protection against shocks and life cycle events. Therefore, social protection policies should be implemented with the following principles: a) Responsive to the realities of needs and living conditions of the target groups; b) Affordable in the context of short and long term budget planning; c) Sustainable, both financially and politically; d) The existence of institutions in a sustainable government structure as well as institutions at the implementation level, especially in the structure of civil society; e) Built on the principle of utilizing individual capabilities, households and communities and avoid creating dependency and stigma and; f) Able to respond to rapidly changing scenarios and the emergence of new challenges;

In Indonesia since 2004, laws related to social protection have been issued, namely Law Number 40 of 2004 concerning the National Social Security System. In this social security system it is recognized that everyone has the right to social security in order to be able to fulfill the basic needs of a decent life and increase their dignity towards the realization of a prosperous, just and prosperous Indonesian society. To provide comprehensive social security, $\mathrm{PKH}$ is conceptually included in the category of social assistance, namely social security programs in the form of cash, goods, or welfare services which are generally given to vulnerable families who do not have a decent income. for humanity. Poor families, unemployed, children, people with disabilities, the elderly,

In the implementation of family-based social protection, according to government policy, it is part of the poverty alleviation program. The program is aimed at the family-based integrated social assistance program group. This program is a social protection policy in the context of fulfilling basic rights. Reducing the burden of living, and improving the quality of life of the poor (Presidential Regulation No. 15 of 2010).

Through Presidential Instruction No. 3 of 2010, the President instructs all Ministers, Heads of Non-Departmental Institutions and Heads of Regions to take the necessary steps according to their respective duties, functions and authorities, to focus, among others, on accelerating family-based poverty reduction programs. $\mathrm{PKH}$ is a social protection program through the provision of cash to RTSM, which in turn are required to make use of health and education facilities. The Family Hope Program is a poverty reduction program that provides cash assistance to Very Poor Households (RTSM) if they meet the requirements related to efforts to improve the quality of Human Resources (HR),

The target or recipients of PKH assistance in the health sector are Very Poor Households (RTSM), namely housewives from families selected through a selection mechanism according to established criteria, namely pregnant women, postpartum mothers, having babies 
and toddlers. In health services, PKH participants receive cash assistance and receive health services (mothers, babies, toddlers) at Puskesmas, Posyandu and others [7].

PKH is a cross-Ministry and Institutional program, the main actor is from the Social Service, then assisted by BPS, Education Office, Health Office, PT. Pos Indonesia, Ministry of Communication and Information, sub-district PKH Office, Non-Governmental Organizations (NGOs), and the Community. Thus, PKH opens opportunities for synergies between programs that intervene on the service side (supply) and Very Poor Households (demand) while still optimizing decentralization, coordination between sectors, coordination between levels of government, and between stakeholders [7].

In the PKH program there are obligations (condinationalities) that must be carried out by Very Poor Households (RTSM) PKH participants related to efforts to improve the quality of human resources. The obligation is related to efforts to improve the health status of pregnant women, postpartum mothers, having babies and toddlers from very poor households.

\section{Method}

This study uses an evaluative research design Stufflebeam namely Context, Input, Process, Product (CIPP). The CIPP model is an evaluation model that views the evaluated program as a system. The population of this study were families who received PKH benefits, amounting to 2117 people. While the sample of this study was determined by purposive sampling with a total of $200 \mathrm{PKH}$ recipients spread proportionally in all villages in Buleleng sub-district. PData collection in this study was carried out by questionnaires, interviews, documentation, and observations. This study uses data analysis techniquesdescriptive percentage [9].

\section{Research Results and Discussion}

The results of the study are described below.

1) Input Effectiveness. The effectiveness of the input is shown by looking at whether the respondents meet the requirements to become PKH recipients. There are two indicators in the input variable, namely meeting at least 9 out of 14 poverty criteria and having at least one of the three PKH components (components of health, education, and social welfare). Respondents are said to be eligible to become PKH recipients if these two indicators are met, while respondents are said to be ineligible to become PKH recipients if they do not meet these two indicators or only meet one of the two indicators. Here are the results obtained:

a. Poverty Indicators

\begin{tabular}{|c|c|c|c|}
\hline \multirow{2}{*}{ Region } & \multicolumn{3}{|c|}{ Poverty Criteria } \\
\cline { 2 - 4 } & $\begin{array}{c}\text { Does not meet } \\
\text { the }\end{array}$ & Fulfil & Total \\
\hline Buleleng District & 63 & 32 & 95 \\
\hline Frequency & $33.32 \%$ & $66.68 \%$ & $100 \%$ \\
\hline Percentage & \multicolumn{3}{|c|}{}
\end{tabular}

The table above shows the poverty level of respondents in Buleleng sub-district. From the table, it is obtained information that in Buleleng district, respondents who meet the poverty criteria by $66.68 \%$ of the total respondents. Meanwhile, respondents who did not meet the poverty criteria were $33.32 \%$ of the total respondents.

b. PKH Component Indicators 


\begin{tabular}{|c|c|c|c|}
\hline \multirow{2}{*}{ Region } & \multicolumn{3}{|c|}{ Poverty Criteria } \\
\cline { 2 - 4 } & $\begin{array}{c}\text { Does not meet } \\
\text { the }\end{array}$ & Fulfil & Total \\
\hline Buleleng District & 2 & 93 & 95 \\
\hline Frequency & $2.1 \%$ & $97.9 \%$ & $100 \%$ \\
\hline Percentage & \multicolumn{3}{|c|}{}
\end{tabular}

From the table above, information is obtained that in Buleleng sub-district, respondents who meet the KPM component are $97.9 \%$ of all respondents. Meanwhile, respondents who did not meet the KPM component were $2.1 \%$ of the total respondents.

c. Input Effectiveness

Based on the poverty indicators and PKH components above, if the respondent meets these two indicators, the respondent is considered to meet the requirements to become a PKH recipient (effective). Meanwhile, if it only fulfills one or both of them, it is said to be ineligible (ineffective).

\begin{tabular}{|c|c|c|c|}
\hline \multirow{2}{*}{ Region } & \multicolumn{3}{|c|}{ Input Criteria } \\
\cline { 2 - 4 } & $\begin{array}{c}\text { Does not meet } \\
\text { the }\end{array}$ & Fulfil & Total \\
\hline Buleleng District & 51 & 58 & 109 \\
\hline Frequency & $46.8 \%$ & $53.2 \%$ & $100 \%$ \\
\hline Percentage &
\end{tabular}

From the table above, the following information is obtained:For Buleleng sub-district, respondents who do not meet the input variable by $66.3 \%$ of the total respondents. Meanwhile, respondents who meet the input variables are $33.7 \%$ of the total respondents.

d. Poverty Indicators Based on Length of Receiving PKH

Long Receiving

PKH

Buleleng District

$<2$ years

25 years

$>5$ years
Does not meet the

\section{Poverty Criteria}

7

$58.30 \%$

28

$65.10 \%$

28

$70.00 \%$
Fulfil

5

$41.70 \%$

15

$34.90 \%$

12

$30.00 \%$

The table above shows the poverty rate in Buleleng sub-district. From the table, the following information is obtained: For the Buleleng sub-district, in the category of receiving PKH for less than 2 years, $58.3 \%$ of respondents did not meet the poverty criteria and $41.7 \%$ of the respondents met the poverty criteria. In the category $2-5$ years, $65.1 \%$ of respondents did not meet the poverty criteria, while $34.9 \%$ of respondents did. In the category of more than 5 years, $70.0 \%$ of respondents did not meet the poverty criteria, while $30.0 \%$ of respondents did.

e. PKH Component Indicators Based on Length of Receiving PKH

\begin{tabular}{cccc}
\hline Long Receiving & & \multicolumn{2}{c}{ KPM Components } \\
\cline { 3 - 3 } PKH & & Does not meet the & Fulfil \\
Buleleng District & & 1 & 11 \\
$<2$ years & Frequency & $8.3 \%$ & $91.7 \%$ \\
& Percentage & 0 & 43 \\
\hline
\end{tabular}




$\begin{array}{llcc} & \text { Percentage } & 0 \% & 100 \% \\ 5 \text { years } & \text { Frequency } & 1 & 39 \\ & \text { Percentage } & 2.5 \% & 97.5 \%\end{array}$

From the table above, the following information is obtained: 1) For Buleleng sub-district, in the category of receiving PKH for less than 2 years, $8.3 \%$ of respondents did not meet the PKM component, while $91.7 \%$ did. In the category $2-5$ years, all respondents or $100 \%$ fulfill the PKM component. In the category of more than 5 years, $2.5 \%$ of respondents did not meet the PKM component, while $97.5 \%$ of respondents met the PKM component. 2) Meet.

Based on the results obtained from the overall effectiveness of the inputs, the ineffective results still seem quite large in each sub-district. In fact, overall in Buleleng Regency, the percentage of respondents who do not meet the requirements $(53.3 \%)$ is higher than respondents who meet the requirements $(46.7 \%)$. This shows that the input variable is still less effective. When viewed from each input indicator, namely the poverty criteria and the PKH component, the majority of respondents meet the requirements for the PKH component, meaning that they have at least one of the PKH components that have been defined. However, in the poverty indicator, there is not too big a difference between those who meet the poverty criteria and those who do not.

There is a possibility that people who have been free from poverty but are still listed as poor are due to weak initial data collection. By becoming a KPM, it is hoped that the community will be free from poverty within 5 years, but in reality there are still many who are listed as poor even though they have received PKH for more than 5 years. This inaccurate data collection is caused by several factors. First, errors in conducting observations and interviews in the field. Field officers assigned to carry out data collection require briefings or intensive training in order to carry out data collection properly. The process of collecting data on people who are classified as poor should be carried out optimally so that poverty alleviation programs can really be addressed to the poor in need. Second, the lack of honesty from the community in reporting their actual economic conditions makes it difficult to collect good data on the real conditions of the community. People may lie so that they can continue to benefit from government programs aimed at alleviating poverty.

2) Process Effectiveness. The effectiveness of the process is seen from the perception of PKH recipients on the mentoring process carried out by local officials. Here are the results obtained:

a. Overall Process Effectiveness

\begin{tabular}{ccccc}
\hline Region & Max Value & $\begin{array}{c}\text { Min } \\
\text { Value. }\end{array}$ & Total & Average \\
\hline Buleleng District & 4.00 & 1.80 & 323 & 3.40 \\
\hline
\end{tabular}

From the results above, categories are made using the ideal mean $(\mathrm{M})$ and ideal standard deviation (SD) with the following formula: For Buleleng sub-district, the overall process variable score is 3.40 , so the average score on the process variable are in the high category. Based on the results obtained, the PKH mentoring process can be considered effective because the community's perception of the mentoring process in all sub-districts in Buleleng is quite good. This shows that the government in each sub-district has shown optimal efforts in providing assistance in order to ensure that the benefits of PKH can be optimally felt by the community. It is undeniable that this good process is also supported by the cooperative attitude of the community in undergoing the mentoring process carried out, 
3) Output Effectiveness. The effectiveness of the output is seen from the fulfillment of the obligations of PKH participants based on their PKH components (Health, education, and social welfare). Here are the results obtained:

a. Overall Output Effectiveness

\begin{tabular}{cccc}
\hline Region & \multicolumn{3}{c}{ Output Criteria } \\
\cline { 2 - 4 } Buleleng District & Ineffective & Effective & Total \\
Frequency & 41 & & \\
Percentage & $43.2 \%$ & 54 & 95 \\
\hline
\end{tabular}

From the table above, information is obtained that: For Buleleng sub-district, $43.2 \%$ of respondents did not meet the appropriate criteria (ineffective), while $56.8 \%$ of respondents met the appropriate (effective) criteria.

b. Output Effectiveness Based on Length of Receiving PKH

\begin{tabular}{cccc}
\hline \multirow{2}{*}{$\begin{array}{c}\text { Long Receiving } \\
\text { PKH }\end{array}$} & & \multicolumn{2}{c}{ Output Criteria } \\
\cline { 3 - 4 } Buleleng District & & Ineffective & Effective \\
\hline$<2$ years & Frequency & 4 & 8 \\
\cline { 2 - 4 } & Percentage & $33.3 \%$ & $66.7 \%$ \\
\hline \multirow{2}{*}{25 years } & Frequency & 20 & 23 \\
\cline { 2 - 4 } & Percentage & $46.5 \%$ & $53.5 \%$ \\
\hline$>5$ years & Frequency & 17 & 23 \\
\cline { 2 - 4 } & Percentage & $42.5 \%$ & $57.5 \%$ \\
\hline
\end{tabular}

Based on the table above, the following information was obtained: For Buleleng subdistrict, in the category of receiving PKH for less than 2 years, 33.3\% of respondents did not meet the appropriate criteria, while $66.7 \%$ met the appropriate criteria. In the category 2-5 years, $46.5 \%$ of respondents did not meet the appropriate criteria, while $53.5 \%$ met the appropriate criteria. In the category of more than 5 years, $42.5 \%$ of respondents did not meet the appropriate criteria, while $57.5 \%$ met the appropriate criteria.

Perception is a series of unconscious processes that a person goes through to understand the stimuli and sensations encountered. The process of perception begins with receiving stimuli from the environment and ends with our interpretation of these stimuli. When a person pays attention to or selects one specific thing in our environment, it becomes a attended stimulus. Organization of stimuli occurs through neural processes; it begins with our sensory receptors (touch, taste, smell, sight, and hearing), and is relayed to our brain, where we regulate the information we receive. Once we receive and organize stimuli, we can interpret those stimuli, which means we take information and turn it into something we can categorize [10]. In the context of perceptions of PKH, what will be seen in this section is how PKH recipients interpret and interpret PKH social assistance in their lives. A positive perception or meaning of $\mathrm{PKH}$ can be said to be a predictor that a person will make good use of this program and vice versa.

\begin{tabular}{|c|c|c|c|c|}
\hline Region & Max Value & $\begin{array}{c}\text { Min } \\
\text { Value. }\end{array}$ & Total & Average \\
\hline Buleleng District & 4.00 & 2.78 & 317.78 & 3.35 \\
\hline
\end{tabular}

From the table above, the following information is obtained: For the Buleleng subdistrict, the average perception score of PKH is 3.35. This value indicates that the respondent's perception of $\mathrm{PKH}$ is in the high category. 
Expectancy is defined as a person's perceived ability to achieve a desired goal and is self-motivating. A person with a higher level of hope has been shown to be positively correlated with better outcomes in academics, physical health, psychological adjustment, and future orientation [11]. In the context of $\mathrm{PKH}$, those with a high level of hope for the program will be better at planning and managing their future lives, to get out of the poverty line.

\begin{tabular}{|c|c|c|c|c|}
\hline Region & Max Value & $\begin{array}{c}\text { Min } \\
\text { Value. }\end{array}$ & Total & Average \\
\hline Buleleng District & 3.22 & 1.89 & 245.78 & 2.59 \\
\hline
\end{tabular}

From the table above, the following information is obtained: For the Buleleng subdistrict, the average score for the variable data expectation is 2.59 . This value shows the average score of the expectation variable is in the medium category.

Psychological well-being is a mental state of well-being characterized by selfacceptance, autonomy, positive relationships with others, having a purpose in life and a desire to continue to develop oneself. Psychological well-being in the context of PKH is a change in the mental state of PKH recipients after receiving this social assistance. The higher the psychological well-being of $\mathrm{PKH}$ recipients, the more it proves the effectiveness of this program and vice versa.

\begin{tabular}{|c|c|c|c|c|}
\hline Region & Max Value & $\begin{array}{c}\text { Min } \\
\text { Value. }\end{array}$ & Total & Average \\
\hline Buleleng District & 3.56 & 2.17 & 263.28 & 2.77 \\
\hline
\end{tabular}

From the table above, the following information is obtained: For the Buleleng subdistrict, the average score for the Psychological Well-Being variable data is 2.77 , so the average score for this variable is in the medium category. 


\section{Conclusion}

The conclusions of the study are as follows. From the input aspect, there are still 33.68 $\mathrm{PKH}$ recipients who do not meet the requirements to become $\mathrm{PKH}$ recipients. This is because many of the respondents do not meet the poverty criteria set by the government. Aspects of the process, the implementation of $\mathrm{PKH}$ is considered to have been running effectively. This shows that the mentoring process carried out by the local government has been going well and has received a positive response from $\mathrm{PKH}$ recipients. As for the output aspect, the majority of respondents (63.3\%) have carried out their obligations as PKH recipients well, while $33.7 \%$ still have not shown satisfactory results. Psychological aspect, this $\mathrm{PKH}$ program turned out to have quite a positive psychological impact. The perception of the PKH recipient community is good in the sense that they really accept the PKH program as a quality program and have the potential to improve their current living conditions. Acceptance is the first layer of someone to accept something. In the future, we just need to provide more repetitive socialization so that the PKH program can be received more clearly and not forgotten. On the aspect of hope, this PKH program is in the medium category. This medium category can be interpreted as an expectation that the community has begun to form that PKH can provide them with a better life. The PKH program has been proven to be able to provide a stimulus to the community to no longer be in poverty. In the future, this expectation needs to be increased again and if possible to record everyone's expectations so that it will be easier to coordinate with related agencies. The last one is on the aspect of psychological well-being, it falls into the moderate category. This means that the PKH program is able to provide sufficient psychological well-being for its recipients. Psychological well-being is very important because it will affect how they behave and act in everyday life The last one is on the aspect of psychological well-being, it falls into the moderate category. This means that the PKH program is able to provide sufficient psychological wellbeing for its recipients. Psychological well-being is very important because it will affect how they behave and act in everyday life The last one is on the aspect of psychological well-being, it falls into the moderate category. This means that the PKH program is able to provide sufficient psychological well-being for its recipients. Psychological well-being is very important because it will affect how they behave and act in everyday life.

\section{References}

[1] Suardika, Made Bimo Abdi. 2020. Macro Poverty Data and Analysis of Buleleng Regency. Singaraja: Teleng Indah Printing

[2] Central Bureau of Statistics. 2016. Percentage of the Poor in March 2016 Reached 10.86 Percent. Available on:https://www.bps.go.id/pressrelease/2016/07/18/1229/persentase-penukur-miskinmaret-2016-menreach-10-86-persen.html. Accessed on August 20, 2021

[3] Nugroho. D, Riant,. 2004. Public Policy, Implementation and Evaluation Formulation. Jakarta: Gramedia.

[4] Tachjan.(2006). Public Policy Implementation. Bandung: AIPI.

[5] Instructions of the President of the Republic of Indonesia Number 3 of 2003 concerning National Policies and Strategies

[6] Kaplan, Robert, S. and Norton, David, P. 2001. The Strategy Focused Organization: How Balanced Scorecard Companies Thrive in the New Business Environment. Massachusetts: Harvard Business School Press.

[7] Directorate of Social Security, Directorate General of Social Protection and Security Ministry of Social Affairs, 2013. PKH Companion Workbook. Jakarta. 
[8] Budiani, NW (2007). The effectiveness of the youth unemployment program "Eka Taruna Bhakti" in Sumerta Kelod Village, East Denpasar District, Denpasar City. Journal of economics and social input, 2(1), 49-57.

[9] Sarman, Koesbiono Hadi. 2000. The Notary Profession in the Era of Globalization, Challenges and Opportunities, Paper at the National Seminar "The Notary Profession Is Approaching".

[10] Authority, Her Kustriyadi. 2002. Prevention and Enforcement of Banking and Financial Crimes, Jakarta: PT. Main Library Gramedia.

[11] Steers, M Richard. (1985). Company Organizational Effectiveness. Jakarta: Erlangga. 